\title{
HERBEAL FEEDING BEHAVIOR OF THE NEW MEXICO MEADOW JUMPING MOUSE (ZAPUS HUDSONIUS LUTEUS)
}

\author{
Greg D. Wright ${ }^{1,2}$ and Jennifer K. Frey ${ }^{1}$
}

\begin{abstract}
We report the first observations of feeding behavior by free-ranging New Mexico meadow jumping mice (Zapus hudsonius luteus). We made observations during a radiotelemetry study of $Z$. h. luteus in the floodplain of the Rio Grande at Bosque del Apache National Wildlife Refuge, Socorro Co., New Mexico, in 2009 and 2010. We observed Z. $h$. luteus eat the achenes or seeds of the order Cyperales: common threesquare (Schoenoplectus pungens), spikerush (Eleocharis spp.), saltgrass (Distichlis spicata), foxtail barley (Hordeum jubatum), Saunder's wildrye (Elymus saundersii), Japanese brome (Bromus japonicus), slender wheatgrass (Elymus trachycaulus), and knotgrass (Paspalum distichum). Mice frequently foraged $0.5-1 \mathrm{~m}$ above the ground in the canopy of herbaceous vegetation. Seed heads for consumption were harvested in several ways.
\end{abstract}

Resumen.-Reportamos las primeras observaciones de la conducta de forrajeo de los jerbos de Nuevo México de la especie Zapus hudsonius luteus. Realizamos observaciones durante un estudio radiotelemétrico del Z. $h$. luteus en las planicies aluviales del Río Grande en el Refugio Nacional de Vida Salvaje del Bosque del Apache, en Socorro Co., Nuevo México, durante 2009 y 2010. Observamos que los Z. h. luteus se alimentan de semillas del orden de los Cyperales: junco (Schoenoplectus pungens), juncia (Eleocharis spp.), pasto salado (Distichlis spicata), cola de ardilla (Hordeum jubatum), centeno silvestre (Elymus saundersii), bromo japonés (Bromus japonicus), pasto agropiro (Elymus trachycaulus) y grama (Paspalum distichum). Los jerbos forrajeaban frecuentemente a 0.5-1 metro sobre el nivel del suelo en el follaje de la vegetación herbácea. Las inflorescencias se recolectaban de diferentes formas para ser consumidas.

The New Mexico meadow jumping mouse (Zapus hudsonius luteus) is endemic to isolated regions of Arizona, Colorado, and New Mexico (Malaney et al. 2012). It is a riparian obligate that utilizes tall, dense herbaceous riparian vegetation on moist soil (Morrison 1992, Frey and Malaney 2009). Due to dramatic declines in its distribution through loss and degradation of riparian habitats, this mouse was listed as endangered with proposed critical habitat under the Endangered Species Act (USFWS 2013, 2014). Most populations of Z. h. luteus are located in montane regions, although a few are known from irrigated floodplains of larger rivers at low elevations, including the Verde River in Arizona, the Florida River in Colorado, and the Rio Grande in New Mexico (Morrison 1990, 1992, Frey 2012, USFWS 2014). The lowest-elevation population of $Z$. h. luteus occurs in the managed floodplain of the Rio Grande at Bosque del Apache National Wildlife Refuge (BANWR), Socorro Co., New Mexico.

During May-August 2009 and May-October 2010, we used radiotelemetry to study habitat selection by Z. h. luteus at BANWR (Frey and Wright 2012, Wright 2012). Our results largely corroborated earlier studies (Morrison 1988, Najera 1994, Zwank et al. 1997) that found $Z$. h. luteus to be most abundant in moist soil—in managed wetland units in spring, and along irrigation canals and drains in summer. Whitaker (1963) found that Z. hudsonius fed on seasonally abundant food sources tied to sufficient overhead cover, suggesting that seasonal shifts in habitat use are in part possibly determined by shifts in food availability. However, few studies have reported on the feeding habits or diet of Z. hudsonius, and none are available for Z. h. luteus. Zapus hudsonius has been reported to eat a wide variety of seeds, fruits, berries, nuts, insects, and fungi, but grass seeds are considered the most important food (Sheldon 1934, Hamilton 1935, Quimby 1951, Whitaker 1963).

When offered grass, captive Z. hudsonius individuals first cut the seed head from the stem and then, holding the seed head with the forepaws, ate the seeds as the seed head was rotated in the forepaws until all seeds had either been eaten or had fallen to the ground as waste.

\footnotetext{
${ }^{1}$ Department of Fish, Wildlife, and Conservation Ecology, New Mexico State University, Las Cruces, NM 88003.

2E-mail: wrightwildlife@gmail.com
} 
The uneaten rachis, spikelets, and fallen seeds form piles that are sometimes found beneath feeding areas in the field (Quimby 1951). Vernon Bailey (1923, 1926:118) described the manner in which Z. hudsonius forages thusly: "To obtain the seeds of grass, on which they mainly subsist, they cut off the tall stems as high up as they can reach, draw them down and cut them off again, and repeat this until the seed-laden tops can be taken." However, it is not clear whether Bailey ever actually witnessed this behavior. In an area where Z. hudsonius was feeding on timothy (Phleum pratense), Whitaker (1963) observed the classic feeding piles consisting of the glumes usually topped by the naked rachis, as well as instances where the seed head was removed but the grass was left standing. Thus, Whitaker suspected that jumping mice were feeding on grass seeds in the manner indicated by Bailey and by climbing grass stems. Prior observations of captive Z. hudsonius suggested that the species is scansorial (Sheldon 1934, Hamilton 1935, Whitaker 1963).

In this paper, we present the first observations of scansorial feeding by Z. hudsonius. Observations were made during our telemetry study of Z. h. luteus at BANWR. When homing in on jumping mice at night, we approached only to about $3 \mathrm{~m}$, a distance which prevented disturbance of the jumping mice and their habitat but still allowed visual observation (Trainor et al. 2007). In some instances, jumping mice approached the observers to closer distances, which allowed for closer observation and digital video recordings of behavior.

On 29 May 2009, while at a distance of 0.5-3.0 m, we observed an adult male feeding on the achenes of common threesquare (Schoenoplectus pungens) from 22:05 to $23: 15$. The jumping mouse was feeding in a moist soil wetland unit, approximately $50 \mathrm{~m}$ from the closest standing water (an irrigation canal). Codominant plant species in this area included Baltic rush (Juncus balticus), common threesquare, dogbane (Apocynum cannabinum), yellow sweetclover (Melilotus officinalis), cocklebur (Xanthium strumarium), and Rio Grande cottonwood (Populus deltoides wislizeni). During this time the jumping mouse did not move more than $7 \mathrm{~m}$. The jumping mouse moved above ground through the dense canopy of Baltic rushes, and it appeared to be searching for the sporadic taller common threesquare. The mouse moved on the ground only when the vegetative canopy was too sparse to support its weight. The mouse's tail was pressed against vegetation and was used as a support to maintain balance and dexterity as the mouse moved about the shifting canopy and perched to feed. Once the mouse located a common threesquare plant, it immediately ascended the stem. If the sedge did not contain spikelets, the jumping mouse continued to climb upward until its weight caused the sedge to tip. As the plant tipped, the mouse held on until alighting softly on the rush canopy, thus being transplanted a horizontal distance of 0.3-0.6 m. If the sedge held a spikelet, the jumping mouse used its teeth to remove the spiklet from the plant. The mouse then used its front paws to rotate the spikelet until all achenes had either been consumed or dropped (e.g., similar to a human eating corn from the cob). The entire process took no more than 15 seconds per spikelet. We referred to the strategic behavior of moving about the herbaceous canopy as herbeal locomotion. This behavior also was noted for the same individual during the nighttime hours of 6 June and 8 June 2009.

Another adult male was observed eating the achenes of common threesquare from 21:00 on 8 June until 02:00 on 9 June 2009. Observations during this period were sporadic due to thick vegetative cover and researchers rotating among several radio-marked jumping mice. The small wetland used by this jumping mouse for feeding had standing water $(<15$ $\mathrm{cm}$ deep) and was dominated by a small stand $(30 \times 15 \mathrm{~m})$ of cattails (Typha spp.). Common threesquare and hardstem bulrush (Schoenoplectus acutus) were interspersed along the edge of the cattails. Again, the mouse's behavior suggested that achenes of common threesquare were actively sought for feeding while all other vegetation was ignored. However, in this case, laid-over bulrushes and cattails at a height of $0.5-1 \mathrm{~m}$ were used as travelways, and common threesquare within reach were climbed and the spikelets removed once the sedge was laid over from the weight of the jumping mouse. The height of this vegetation made observation difficult, and the act of using thick vegetation as travelways was seen only a few times.

On 2 July 2009, we observed another adult male in the first wetland described, but this mouse was feeding on knotgrass (Paspalum distichum). The mouse was observed sporadically 


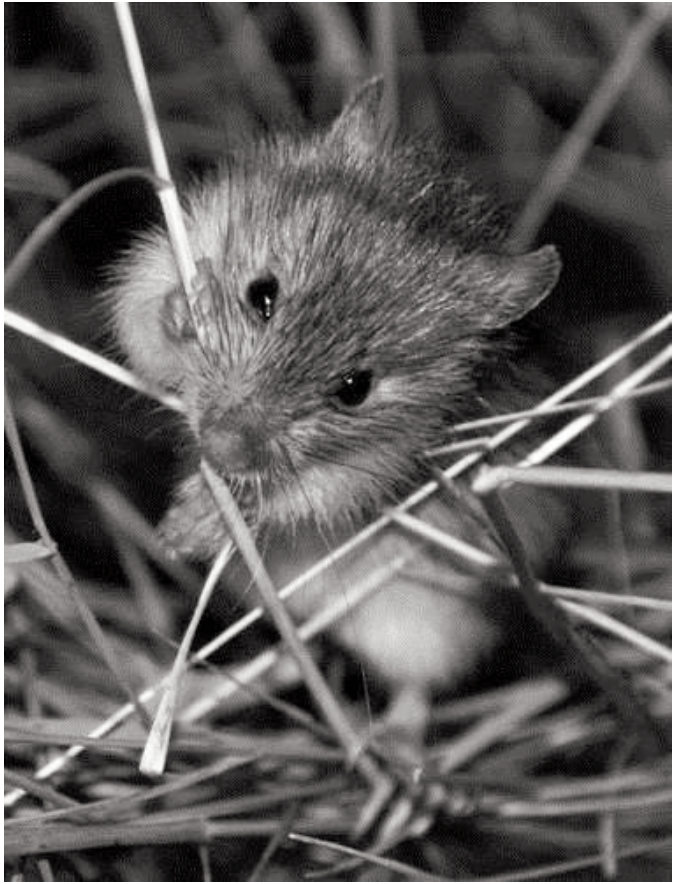

Fig. 1. A pregnant New Mexico meadow jumping mouse (Zapus hudsonius luteus) in the herbaceous canopy harvesting a grass inflorescence. Bosque del Apache National Wildlife Refuge, Socorro County, New Mexico, 30 July 2010.

from 21:25 on 2 July until 01:51 on 3 July 2009 . Irrigation water was flowing into the wetland where the jumping mouse was observed. The jumping mouse was in an area containing mainly annual rabbitsfoot grass (Polypogon monspeliensis), smartweed (Polygonum spp.), and knotgrass. Rabbitsfoot grass grew thickly and was laid over at a height of approximately $15 \mathrm{~cm}$. Knotgrass was interspersed among the carpet of rabbitsfoot grass, and the jumping mouse simply crept over the grass canopy until a fruiting knotgrass was located. The jumping mouse sat on its haunches on the grass canopy and removed these low-growing seeds without detaching the entire inflorescence from the plant. This behavior was observed over a period of $<10 \mathrm{~min}$, as the vegetation was sparse and we felt that longer observation would disturb the animal.

From 00:05 until 04:59 on 22 May 2010, we observed an adult male eating the green seeds of Japanese brome (Bromus japonicus) by standing on its hind legs and reaching up to grasp the stem of the plant. The seeds of this flexible plant were then pulled within reach and consumed. From 21:29 on 23 May until 03:05 on 24 May 2010, we observed the same individual foraging on the achenes of spikerush (Eleocharis spp.) by traveling along the surface of the dense mat the spikerush created within a moist streambed. The same night, we observed another male eating the seeds of saltgrass in much the same manner that seeds of Japanese brome were consumed.

On the night of 21 June 2010, we observed an adult male eating the seeds of foxtail barley (Hordeum jubatum) beneath a canopy of regenerating narrowleaf willows (Salix exigua). The seeds were consumed in the same manner as those of Japanese brome and saltgrass. Foxtail barley was locally abundant in areas occupied by Z. h. luteus, yet this was the only instance when jumping mice were observed feeding on the plant.

During darkness between 29 July and 3 August 2010, we observed a pregnant adult female feeding on the seeds of bunchgrasses, Saunder's wildrye (Elymus saundersii) and slender wheatgrass (Elymus trachycaulus), in a manner similar to that described by Bailey (1923, 1926). The jumping mouse was at the edge of a flooded irrigation canal, and even though many potential food plants were available near this location, these 2 grasses were the only species consumed by the jumping mouse. While perched within the base of the bunchgrass, the jumping mouse cut the stem containing the seed head and then pulled it down "paw over paw" until the seeds were within reach (Fig. 1). After several nights of this behavior, the water rose and partially submerged the base of the bunchgrass, and the jumping mouse altered its behavior by cutting the grass stems multiple times as it lowered the seeds to within reach. This behavior was observed only when the area was flooded and flowing water prevented the jumping mouse from lowering the first cut edge to the ground to obtain seeds. The discarded clippings formed a platform within the base of the bunchgrass just above the water's surface, on which the jumping mouse remained perched above the water as the slender wheatgrass clump was depleted of seeds.

Prior studies found that tall, dense herbaceous vegetation is a key microhabitat requirement for Z. h. luteus (Morrison 1990, Frey and Malaney 2009). Our observations provide partial 
explanation for the importance of this vegetation structure. Perhaps most importantly, dense herbaceous vegetation provides the needed scaling structure for jumping mice to reach otherwise inaccessible food items and allows the mice to continue feeding even when their habitat is flooded and fallen seeds are thus unavailable. Quimby (1951) noted that captive Z. hudsonius ate only seeds from the plant and never attempted to retrieve fallen seeds. Thus, this scansorial foraging habit is fundamentally different from the behaviors of many granivorous rodents that primarily forage on fallen seeds. The apparently common scansorial foraging habits of $Z$. $h$. luteus might partially explain the difficulty in capturing the species compared to other rodents that readily consume fallen seeds. Herbeal locomotion also may reduce predation risk and allow jumping mice, which are relatively docile (Whitaker 1972), to avoid confrontation and competition from larger, more aggressive small mammals, such as voles (Microtus; Boonstra and Hoyle 1986) and the hispid cotton rat (Sigmodon hispidus), which was the most common small mammal captured during our study at BANWR (Wright 2012).

This study was designed to investigate multiple life-history stages of $Z$. h. luteus throughout the active period of the species from May to October. Observations of feeding by jumping mice were opportunistic, and some annual feeding behaviors, such as those during maternal nesting, remain a mystery. Of the 8 plant species that we observed $Z$. h. luteus consuming, 6 were grasses, even though grasses often were not dominant plants in habitats used by the species at BANWR (Wright 2012). Unlike prior reports, we never observed Z. h. luteus consuming insects, although we could have missed infrequent events. In contrast, achenes of common threesquare seemed to be an important food for this population of $Z$. h. luteus during the several weeks following emergence from hibernation in mid-May (Najera 1994). Emergence from hibernation is considered a particularly stressful time for Z. hudsonius due to low food availability, low body weight, and high reproductive activity (Hoyle and Boonstra 1986). At BANWR, achenes of common threesquare appeared to be available earlier than those of most grasses; hence this species may be a necessary food source for this population of Z. h. luteus during spring.
This study was funded by the U.S. Fish and Wildlife Service (Agreement \#201819806). We thank John Vradenburg, Ashley Inslee, and the staff of Bosque del Apache National Wildlife Refuge for their logistical assistance, and Jim Stuart, Angelina Wright, and Caitlyn Casey for help in the field.

\section{Literature Cited}

Bailey, V. 1923. Mammals of the District of Columbia. Proceedings of the Biological Society of Washington 36:103-138

1926. A biological survey of North Dakota. I. Physiography and life zones. II. The mammals. North American Fauna 49:1-226.

Boonstra, R., And J.A. Hoyle. 1986. Rarity and coexistence of a small hibernator, Zapus hudsonius, with fluctuating populations of Microtus pennsylvanicus in the grasslands of southern Ontario. Journal of Animal Ecology 55:773-784.

FrEY, J.K. 2012. Evidence for the historical occurrence of the meadow jumping mouse in the Verde River watershed, Arizona. Western North American Naturalist $72: 257-262$.

Frey, J.K., AND J.L. MaLaney. 2009. Decline of the meadow jumping mouse (Zapus hudsonius luteus) in two mountain ranges in New Mexico. Southwestern Naturalist $54: 31-44$.

FreY, J.K., AND G.D. Wright. 2012. Multiple scale habitat selection by a small mammal habitat specialist (Zapus hudsonius luteus) in a managed floodplain landscape. Final report submitted to U.S. Fish and Wildlife Service, Cooperative Agreement 201819J806, 16 March 2012. 109 pp.

Hamilton, W.J., JR. 1935. Habits of jumping mice. American Midland Naturalist 16:187-200.

Hoyle, J.A., AND R. BOONSTRA. 1986. Life history traits of the meadow jumping mouse, Zapus hudsonius, in southern Ontario. Canadian Field-Naturalist 100: 537-544.

Malaney, J.L., J.K. Frey, and J.A. CoOK. 2012. The biogeographic legacy of an imperilled taxon provides a foundation for assessing lineage diversification, demography, and conservation genetics. Diversity and Distributions 18:689-703.

Morrison, J.L. 1988. Distribution, life history and ecology of the meadow jumping mouse, Zapus hudsonius luteus, at four sites along the Rio Grande Valley in New Mexico. Unpublished report to New Mexico Department of Game and Fish, 15 February 1988. 57 pp.

1990. The meadow jumping mouse in New Mexico: habitat preferences and management recommendations. Pages 136-143 in P.R. Krausman and N.S. Smith, editors, Proceedings of the Symposium on Managing Wildlife in the Southwest. Arizona Chapter, The Wildlife Society, Phoenix, AZ.

1992. Persistence of the meadow jumping mouse, Zapus hudsonius luteus, in New Mexico. Southwestern Naturalist 37:308-311.

NajerA, S.R. 1994. Meadow jumping mice habitat affinities and capture success in two trap types at Bosque de Apache National Wildlife Refuge. Master's thesis, New Mexico State University, Las Cruces, NM. 86 pp. 
Quimby, D.C. 1951. The life history and ecology of the jumping mouse, Zapus hudsonius. Ecological Monographs 21:61-95.

SHELDON, C. 1934. Studies on the life histories of Zapus and Napaeozapus in Nova Scotia. Journal of Mammalogy $15: 290-300$

Trainor, A.M., T.M. Shenk, And K.R. Wilson. 2007. Microhabitat characteristics of Preble's meadow jumping mouse high-use areas. Journal of Wildlife Management 71:469-477.

[USFWS] United States Fish and Wildlife Service. 2013. Proposed rule. Proposed designation of critical habitat for the New Mexico meadow jumping mouse. Federal Register [20 June 2013] 78(119): 37328-37362.

. 2014. Final rule. Determination of endangered status for the New Mexico meadow jumping mouse throughout its range. Federal Register [10 June 2014] 79(111):33119-33137
Whitaker, J.O., JR. 1963. A study of the meadow jumping mouse, Zapus hudsonius (Zimmerman), in central New York. Ecological Monographs 33:215-254.

1972. Zapus hudsonius. Mammalian Species 11:1-7.

WRIGHT, G.D. 2012. Multiple scale habitat selection by a small mammal habitat specialist (Zapus hudsonius luteus) in a managed floodplain landscape. Master's thesis, New Mexico State University, Las Cruces, NM. 109 pp.

Zwank, P.J., S.R. Najera, and M. Cardenas. 1997. Life history and habitat affinities of meadow jumping mice (Zapus hudsonius) in the middle Rio Grande valley of New Mexico. Southwestern Naturalist 42:318-322.

Received 25 June 2013 Accepted 20 December 2013 